\title{
The Rise of Islamic State of Iraq and Syria (ISIS)
}

\author{
Luna SHAMIEH ${ }^{1}$, SZENES Zoltán ${ }^{2}$
}

\begin{abstract}
Europe and Hungary, currently faces multiple national threats in an environment of growing disorder. ISIS, the "State of Terror", is executing a sophisticated strat- egy that involves simultaneous efforts and attacks in Iraq and Syria, the Middle East and North Africa, and the wider world. Civil wars are intensifying in Ukraine, Yemen, and Libya, causing massive migration waves. The recent terrorist attack in Paris has shown that ISIS supported homegrown terrorism is an increasing threat. This article discusses the development and internal issues of the most dangerous terrorist organization. Although it was not a purpose to analyze the international consequences of the recent ISIS attack in Paris, the authors express their hope that ISIS might make a strategic mistake. On $13^{\text {rd }}$ November, 2015 can be a turning point in the fight against the Islamic State.
\end{abstract}

Keywords: ISIS, Islamic State of Iraq and the Levant (ISIL), DAESH - the Arabic equivalent of ISIL, Islamic State, terrorism, jihadist, Iraq, Syria

\section{Islam and Politics}

The Islamic religion has been associated with politics since its establishment. The prophet Muhammad was a religious and political leader for the people "Ummah". ${ }^{3}$ He worked as a political leader in different aspects and conducted many successful military expeditions with different parties throughout his leadership period. Additionally, he worked as a judge and helped resolve conflicts and disputes for his people, which made him the reference for the "Ummah" in multi-disciplinary aspects including cultural, family disputes, and even eco- nomic issues that might have risen. Furthermore, he initiated relationships with neighboring countries especially in the relationship with the King of Ethiopia to seek asylum. Hence, sev- eral incidents and occasions reveal the relationship between the religion and politics during the prophet's leadership.

After the prophet the political leadership continued, especially after his death when the followers discussed who would take over the leadership. During this phase disputes aroused in ruling the vast Caliphate that the Prophet Muhammad established. The Caliphate is the government system in which an Islamic political leader leads the Ummah in accordance to the Islamic ideologies.

Two parties were evident in the dispute that resulted from whom would rule the Ummah after the death of the prophet; one that was in favor of electing a successor (Calipha) and

1 Ph.D. Student, National University of Public Service, Budapest, Hungary, e-mail: shamia.luna@uni-nke.hu

2 Professor of Security and Defense Studies, National University of Public Service, Hungary, e-mail: szenes. zoltan@uni-nke.hu

3 The word literally means community or people. When it comes to Islam, it means the whole community of Muslims bound together by ties of

religion. There are many sects within the Muslim community, but the whole of it is considered Ummah. The word encompasses everyone who is a Muslim. 
the other argued that it should go to Muhammad's son in law Ali bin Abu Taleb who was nominated by the prophet before his death. Ali became the fourth caliph but was murdered in the city of Kufa. Twenty years later, Ali's followers were travelling with his son to Karbala where he was mascaraed with his fighters in Karbala. Accordingly, Kufa and Karbala are now considered the heartland of Shia Islam.

In the past few years Sunni and Shia disputes have regressed to conflicts and they have now become a serious issue of conflict in the region. Shia mainly exists in Iran, part of Iraq and Bahrain; though they are minorities in other regions. Figure 1 shows the distribution of both parties. Iran, Iraq, and Bahrain include the largest Shia communities that comprise 89 ,

60 , and $70 \%$ respectively.

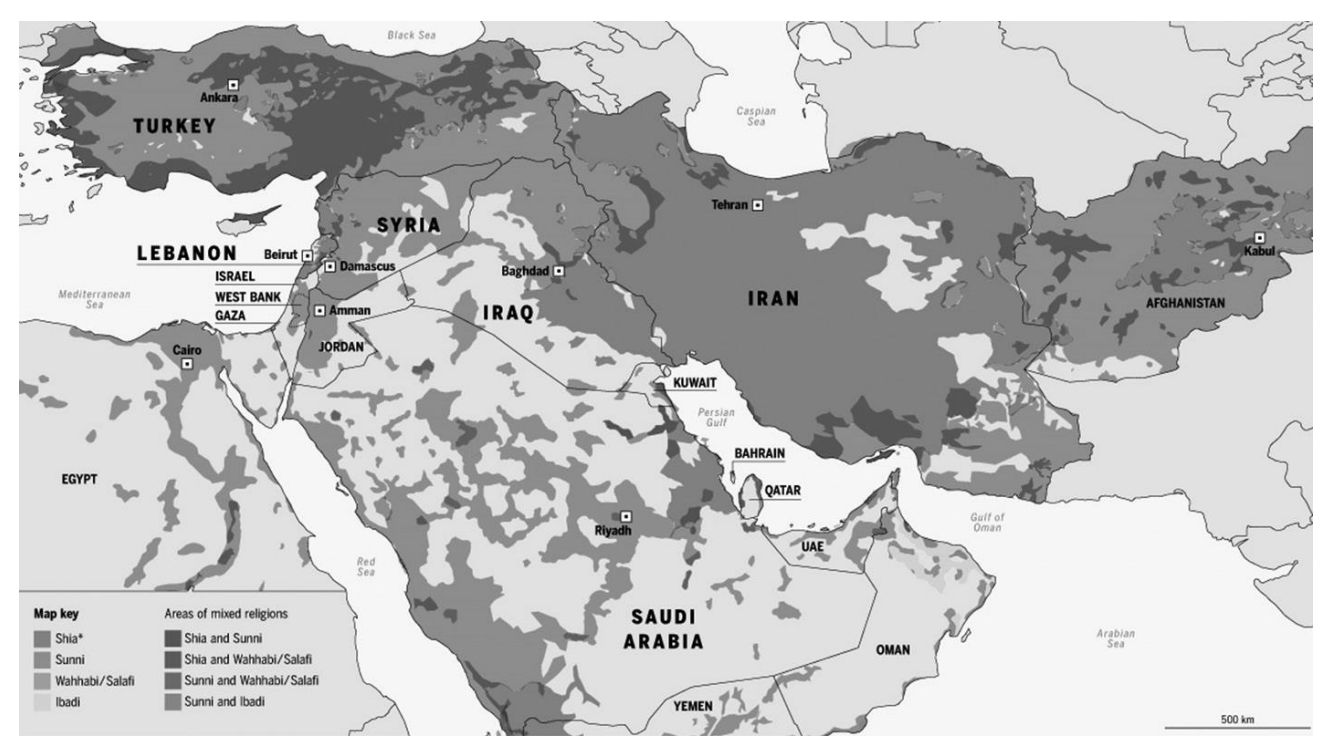

Figure 1. Distribution of Sunni and Shia in the Middle East. [32]

\section{Iraq and Syria: The Fertilized Land}

The political situation in both Iraq and Syria permitted for the expansion of ISIS. Both coun- tries included internal conflict and growing seeds of struggle. This made the expansion of ISIS in the region possible.

To identify allies and enemies it is worthy to going back to the Iraqi case to defines some of the roots of the case. The Kurds, who are currently in a decisive war and fights with ISIS, had faced a devastating situation during Saddam Hussein's rule of Iraq. In 1988 the Iraqi leader Saddam Hussein used chemical weapons to kill tens of thousands of Iraqi Kurds in the north of the country to gain control of the oil wealth in that region. This conflict led to resentment and hatred between the Saddam Regime and the Kurds. Furthermore, as a Sunni leader, who was in favor of the Sunni over the Shia; the regime favored Sunni people for employment purposes. Hence, although Saddam Hussein was able to keep the country as one he helped create political tensions that catalyzed the current situation. 
Another main catalyst that helped keep the region on the boiling is the Iraqi invasion. On $2^{\text {nd }}$ August, 1990 Iraq invaded its neighboring country Kuwait, as was a result of disputes about oil production. This led to the UN sanctioned international coalition led by the USA, who used ground, maritime and air forces to force Iraqi troops to leave Kuwait. Within days the Iraqi forces were forced out. [1] However, the sanctions never came to an end even after the ceasefire. A no-fly zone was inflicted until the second invasion of Iraq. (See Figure 2.) This no-fly zone helped empower the Kurds in the north and empower the Shia in the south. After the termination of the Saddam Regime through the Iraq invasion in 2003, a new weak Shia regime was established. Hence the weak government and system lived at the tensions that led to failed statehood facilitated internal conflicts, especially with the existence of three different parties (Shia, Sunni, Kurds), with different visions and different views of the new Iraq.

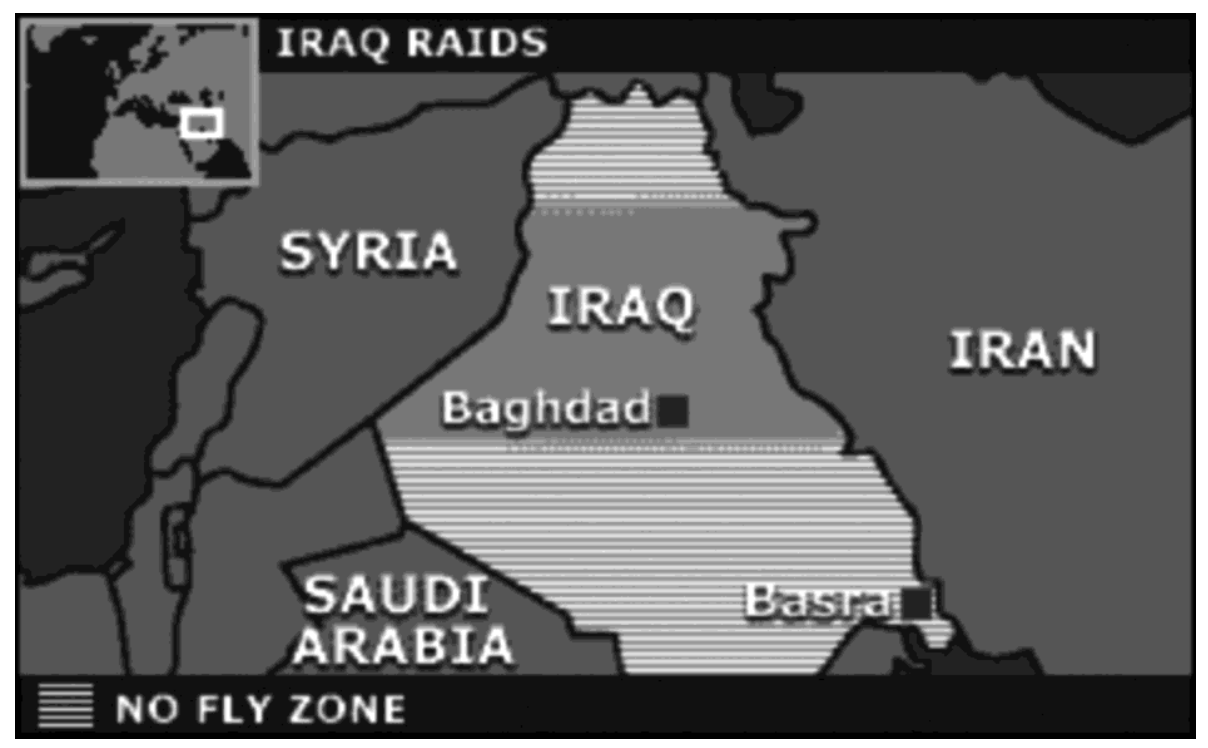

Figure 2. No-fly zone in Iraq between 1990 until 2003. [33]

Syria is another region that has been facing internal conflict to a large extent since 2011. Many people were against the Assad Regime and the opposition has been getting bold. The rebels have become more and more effective and extreme. [2] In 2014 the inter-level conflict erupted among the Opposition Forces in the Syrian Civil War. Large opposition groups are fighting with each other: the Free Syrian Army (FSA), the Army of Mujahedeen, the Islamic Front, and the Islamic State of Iraq and Syria, amongst whom ISIS is the strongest one. The Islamic State - according to the regional Arabic resources - has about 10,000-100,000 fight- ers (estimated number, the figures are extraordinarily wide-ranging) [3] alone which equal with the strength of other rebel groups together. Since Syria has been a failed state system, she is easily accommodated the rebel movements like ISIS. 


\section{Establishment}

The story of ISIS goes back to Abu-Musab Al-Zarqawi who was imprisoned in Jordan for 5 years, after being sentenced 15 years for the possession of weapons and being affiliated to the Bayat al-Jihadi. Zarqawi then left go to Afghanistan and made contact with al-Qaeda where he was able to establish the Jihadi Group Jund al-Sham; which was named later "Jama'at al- Tawhid wal-Jihad". One of their main activities was the bombing of some tourist sites in Jor- dan in 1999. One of these explosions was the Radisson SAS Hotel in which Sajida Al-Rish- awi was one of the terrorists who attempted to blow herself up, but failed to do so. Sajida al-Rishawi has remained in the Jordanian prisons since then and was most recently requested by ISIS as part of the prisoner swap agreement with the Jordanian pilot Muath Kassasbeh. Shortly, after the explosions incidents, Zarqawi and his people relocated to northern Iraq.

Zarqawi established the Jama'at al-Tawhid wal-Jihad in the Kurdish area of Sulaymaniya which was targeted by the US troops during the 2003 US invasion of Iraq. This group had three major targets: the Shia, the international community, and Jordan; and hence their terror- ist activities were conducted as such. In September 2004, Zarqawi announced the allegiance with al-Qaeda; where the group was then called al-Qaeda in Iraq. ${ }^{4}$

The relationship between al-Qaeda in Iraq and al-Qaeda was tense due to the different visions and strategies of both groups. However, the group remained to attract supporters and followers. Ideologically, all followers come from the Jihadi movement; which is very similar to Saudi Wahhabism ${ }^{5}$ and who believe that the Shia to be heretics. Zarqawi died in June 2006, and al-Qaeda in Iraq appointed Abu Ayyub al-Masri as the new leader. Four months later the Islamic State in Iraq (ISI) "Dawla al-Islamya fi Iraq" was established with a fully structured cabinet. [6]

In $15^{\text {th }}$ October, 2006 a jihadist website revealed a recorded statement by the Mujahidin Shura Council declaring the establishment of the "Islamic State in Iraq": "After the Kurds had secured a state in the north and the Rawaf, ${ }^{6}$ had won approval for federalism in the south and center with the support of the Jews in the north and the Safawis ${ }^{7}$ in the south, protected by armed militias that have black hearts, ideology, and action - militias that have been kill-ing our Sunni people and subjecting them to the ugliest forms of killing, torture, and displace-ment. The condition of the Sunnis has become the same as the condition of the orphans on the table of wicked people. Therefore, it has become a must for the honorable and free Sunni mujahidin, ulema, ${ }^{8}$ and notables to make something for their brothers, sons, and honor in light of this silly drama that is called Al-Maliki's state, in which it was regrettable that Sunni traitors took part. By doing so, they confused the religion for the people and deliberately wasted the rights of their people. [7]

The statement included the vision for establishing the new group. It also identified the allies and the enemies. In 2006, the Islamic State of Iraq's Leader Abu Omar Al-Baghdadi

4 The Hungarian ISIS experts have similar timeline for establishing of the terrorist organization. [4] [5]

5 Wahabism is a religious group that stared in Saudi Arabia by Muhammad ibn Abd al-Wahhab. Abd al-Wahhab demanded that all Muslims should pledge allegiance to the Caliph, and those who do not follow him should be killed.

6 Derogatory term for Shiites.

7 Reference to Iranians. Men of knowledge, teacher or authority.

8 Men of knowledge, teacher or authority. 
then claimed that supporters were growing and organization of the group had started with self-sufficiency. Their control started widening, although it was only by early 2007, that the local tribes started combating the ISI troops, this started in Anbar province with what was called the Sahwa "awakening" movement. [8] As a result the Islamic State suffered signifi- cantly during the Sahwa, until 2009.

From June 2009 until August 2010 the US military withdrew from Iraq, this weakened the Sahwa efforts. The US commander in Iraq General Lloyd predicted this weakening. He sum- marized the US-Iraqi relations in November 2011 as follows: "As we leave, we can expect to see some turbulence in security initially, and that's because you'll see various elements try to increase their freedom of movement and freedom of action," despite better conditions than at any other point, "there will probably be unfinished business for many, many years to come [...] al-Qaeda will continue to do what it's done in the past, and we expect that it's possible they could even increase their capability." [9]

This withdrawal not only weakened the Sahwa group, but also left a weak Iraqi govern- ment unable to deliver the required services. The Nouri al-Malki's Shia-led government was unable to pay the wages or to provide security to the people. [9] ISI on the other hand was providing better salaries for its people. This facilitated local recruitment from Iraq, which facilitated social grounding. This led to expansion in controlling wide areas, and expansion in the number of military operations conducted. This facilitated their campaign "breaking the walls". The campaign helped free ISIS members from the Iraqi prisons.

The internal conflict in Syria and the expansion of ISI helped spread of the ISI to Syria. In early 2012, the Syrian revolution turned to armed struggle, which facilitated the work of Jihad- ist groups. The al-Nusra Front was established in Syria on January, 2012. The Nusra Front is a Jihadist group that was in opposition to President Bashar Assad in Syria. The group justified its existence and was also accepted by the people due to its acts against the Assad regime and through Islamic theological rule. [10] That was the crucial moment that changed the revolu- tionary style to a mechanism that welcomes jihadist movements. Leaders of the group avoided declaring affiliation with ISI or al-Qaeda, although ISI did support al-Nusra with men and funds. In 10 ${ }^{\text {th }}$ April, 2013, Abu Bakr al-Baghdadi announced the merger of al-Nusra to form the Islamic State that expanded to Syria. [10] Hence, the name started as the Islamic State in Iraq and Syria, which is known as ISIS or ISIL. However, Abu Muhammad Al-Julani (leader of al-Nusra) denied his knowledge of the decision and renewed his pledge of allegiance to al-Qae- da leader Ayman Zawahri. Hence, conflict erupted and the majority of the nonSyrian followers welcomed the merge with ISIS. Though Syrian followers decided not to join the al-Baghdadi group, others were not in favor of any and joined Islamic parties as Ahrar al-Sham.

\section{The Name}

Different names are used for the militant group operating in Iraq and Syria; different naming refers to different positions and ambitions. The following are the names used:

- ISIS: the name ISIS is an acronym for the Islamic State in Iraq and Syria. The group revealed this name first. Currently, this is the name used by the media and the public.

- ISIL: the Obama Administration calls it ISIL acronym for Islamic State in Levant. This means that the geographic location includes the whole Levant including Jordan, Lebanon and Palestine. 
- Daesh: this is the name used by the Arab States, since it refers to the Arabic Acronym of the name "Al-Dawla AlIslamiya fi al-Iraq wa al-Sham" which is the Islamic State in Iraq and Sham.

- Islamic State: This is the name the group call themselves and this reflects their am- bition; an Islamic State without borders. They claim to represent the Muslims every- where. Even if they have the ambition of extending the Islamic State to the Closer World (see Figure 3 for the map). As shown in the map below the Islamic State in- cludes Iraq, Sham (this part includes Syria, Lebanon, Jordan, Palestine, and Israel), Hijaz (Saudi Arabia, Kuwait, Bahrain, Qatar, United Arab Emirates, Oman), Yaman (Yemen) the land of Alkinana (Egypt, Libya) Maghreb (Algeria, Morocco and Mau- ritania), the land of Habasha (Sudan, Somalia, Djibouti), Khurasan (Iran, Afghani- stan, Pakistan, Kazakhstan, India, and parts of China), Andalaus (Spain, which is the same name that was used during the Islamic government), Orobpa (Europe), Anathol (European part of Turkey), Kurdistan (parts of Syria, Turkey, Iraq and Iran), Qoqzaz (Caucasus area).

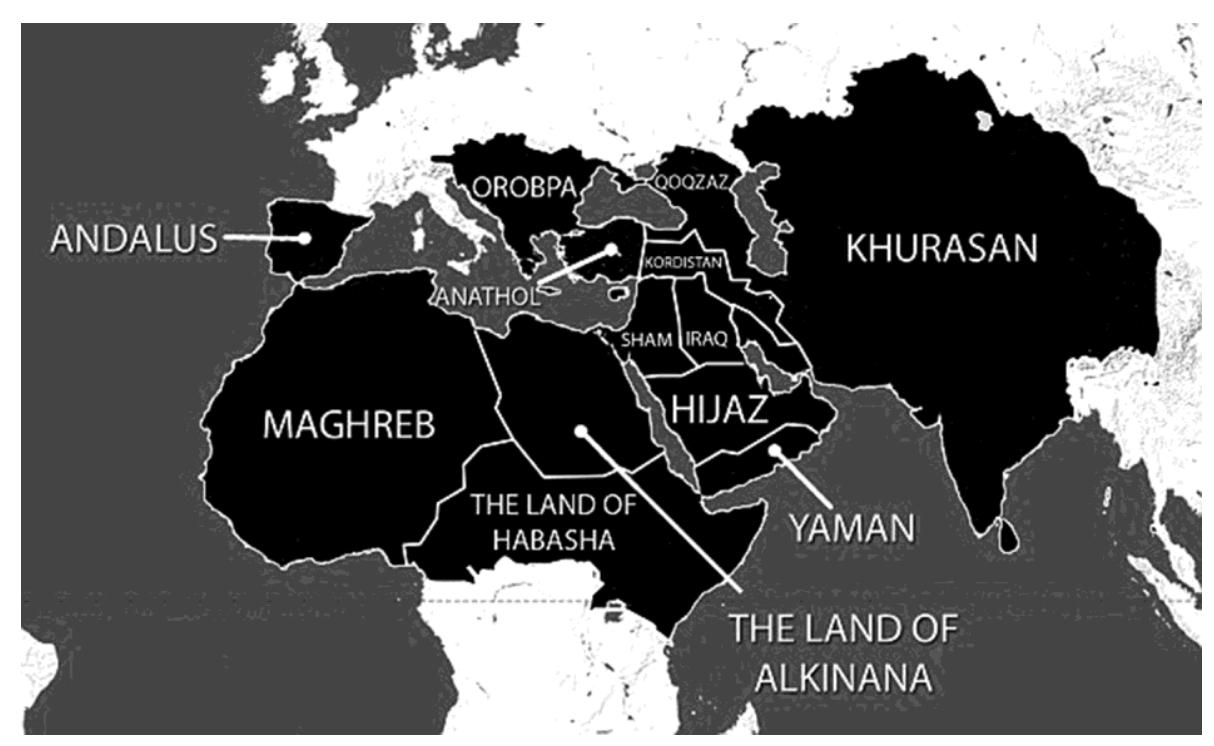

Figure 3. Islamic State according to ISIS. [11]

\section{Al-Qaeda Ideology vs. ISIS Ideology}

Al-Qaeda and ISIS have many similarities in the vision and organization. Both parties were looking forward to having a transnational Islamic State that would be established in the max-imum geographic locations possible. Both groups were looking for the Islamic Government system, the Caliphate, following the Islamic Sharia and having the Caliph as the centralized political and Islamic leader who will give the orders and the Ummah will have to follow them. All disputes and courts will follow Islamic Sharia. For example, thieves should have their hands chopped off in public, and several other Islamic legal verdicts. It is apparent that 
both groups have modern technology mechanisms and very well established public relations and advocacy plans. They both use social media for spreading news, progress and proclaimed plans

However, despite of the unified origin of both groups, they are different in two main as- pects. First, they differ in the strategy they are working with. Al-Qaeda started its work with external strategies focusing on the external relations, [12] which is apparent through the $9 / 11$ attacks and the London bombing. The advocacy of the groups was focused on fights against the people of other countries to ensure that their ideology will be inflicted. On the other hand, IS had the opposite strategy, they were focused on their people and all brutal acts were in- flicted on their own people.

From an organizational perspective it could be called a "vanguard" group according to the political scientist Paul Staniland. [13] This means that the group has a tight central lead- ership; however, it is not as strongly embedded within the community. Especially, because most people are against the idea of this extremist ideas and strategy.

Another difference is based on the target group of both IS and al-Qaeda. The Islamic State calls upon its people, and this is limited to Sunni people. They are against any non-Sunnis people. They kill Shia and Christians; they are even against Sunnis who are not in favor of their strategy. They try to control the region of Iraq and Syria. ISIS believes that full control of this region will help them move to their second step. All their activities are based on their region, as they perceive that they cannot move forward to any new battles until they are done successfully with the current battle.

Currently, no one is concerned about al-Qaeda ideology, despite the fact that the war against terrorism started against this specific group. The ideology, the group, and the term are diminishing with time. This diminishing was never a result of the war against terrorism despite all the activities and operations against al-Qaeda, nor did it neither collapsed due to the change of people's thinking; moreover, it was not defeated by any local war. The only cause of this defeat was the arising of ISIS; ISIS started to compete with the ideology, the mechanism and the strategy of establishing an Islamic State. It is even accepted as an ideol- ogy amongst youth coming from different origins and religions.

\section{ISIS Organization}

The Islamic State is a very well organized group, this is apparent through the structure they are using and most importantly through the progress they are accomplishing. The following factors assure the well-organized system of the group.

\section{Organizational Structure}

The group has a well-developed organizational system of state, which might be even more developed that existing states in the region. It includes the three authorities of an established state:

1. Judicial authority: according to their system includes:

a) Islamic courts.

b) The Judicial Authority: this deals with all judicial matters. 
2. Legislative authority: for ISIS this includes:

a) The Shura (Consultative) Council: this council includes 9-11 members, all select-

ed by the Caliph. The main task of the Council is supervising affairs the state.

3. Executive authority: the executive part includes defense, military, and public relations:

a) Military: the Military Council: includes three members appointed by the Caliph. The council is responsible for planning and supervising military actions and operations.

b) Security: the Defense, Security and Intelligence Council: it is responsible for the security of the Caliph, and most importantly of implementing orders, campaigns, judicial decisions and, intelligence purposes.

c) Public Relations for disseminating the messages of the Caliph.

Additionally, the scale of manpower is helping the progress of ISIS. Some statistics say that number of fighters ranged from 7,000 to 12,000 with many recruits arriving on a daily basis. [14]

\section{Financial Status}

During its establishment ISIS received financial support from the Gulf; however, currently they are self-funded. They have the illicit sale of oil through oil wells and refineries they con- trol to the black market. Moreover, they control many of the ancient artifacts they have stolen from the region. Also, they are able to gain money through hostages, the taxes people pay are secured (for example Christians), and businesses they are starting. Reports claim that ISIS is the richest terrorist organization in the world. According to Colin (2014) IS had 8 million US dollar net monthly income through the businesses in Mosul alone.

\section{Use of Information and Communication Technology}

ISIS personnel are highly skilled and active in IT; they post high quality videos with remark- able and advanced technology. They use the videos to send their PR messages, show their operations clearly and the progress they make in each operation. They conduct interviews with hostages declaring they are not a bloody group, and interviews with citizens who thank them for the bravery, work and for saving their lives by ending the Sykes-Picot borders. They also release their reports to the public. They work in different languages English, Arabic, German and French.

Additionally they are very active on social media; they post thousands of Facebook mes- sages and twitter tweets. IS has created a twitter application that helps them to send all links, hashtags, and images.

\section{Armaments}

ISIS is well equipped with advanced rockets mortars and different types of weapons. Accord- ing to Bender (2014) ISIS has different types of armor, including ones made by the Russians, the Chinese and the US. These include: T-55 tanks, T-72 tanks, Humvees, AK-47s, M79

OSA Rocket Launcher, RBG-6 Grenade Launcher, RPG-7s, M198 Howitzer, Type 59-1

Field Gun, ZU-23-2 Anti Artifact Gun, FIM-92 Stinger, MANPAD, HJ-8, and DShK-1938

Machine Gun. [15] 


\section{ISIS Public Support}

Despite the fact that islamization is increasing in the Middle East, which is apparent in the customs and traditions of the people there; however, not many accept the idea of ISIS. Ac- cording to Pew Research (Global Attitudes Project), [16] the "Middle Easter sees religious and ethnic hatred as a top global threat. A huge number of Muslims are against the extremism of the group. They do accept the Islamic Sharia; however, they do not accept the strategy of the IS." In a study done by the Washington Institute in October 2014; only 5\% from Saudi Arabia support ISIS, 3\% in Egypt, and none in Lebanon supports ISIS. [17] However, other reports indicate that there are many supporters of ISIS in Jordan, and people are traveling to Syria to support ISIS. [18] Moreover, Taliban in Pakistan are highly in favor and ready to support ISIS. [19] Additionally, "Ansar Bait al-Maqdis" ("Champions of Jerusalem"), an extremist militant group who is active in Sinai and is in alliance with the Islamic brother- hood the previous Egyptian government announced its allegiance with ISIS. Since then the group named itself "Wilayet Sinai", Province of Sinai. They announced: "After entrusting God we decided to swear allegiance to the emir of the faithful Abu Bakr al-Baghdadi, caliph of the Muslims in Syria and Iraq and in other countries." [20] This group has announced several times that it would be working against the Egyptian army. Also, ISIS in its website declared that the Islamic Group of Morocco has also announced its alliance to the Islamic State, through a letter that requests support from all the Muslims in the Iraqi and Syrian re- gions. [21]

Reports have indicated that Muslim supporters of the ISIS in Europe are in existence. "One in seven young British adults has 'warm feelings' towards the Islamic State, and a tenth of Londoners and one is 12 Scots views Islamic State favorably." Which was appar- ent more for those of ages 18 to 34 years old, [22] another survey conducted in France, UK and Germany indicated that almost a sixth of the French population (16\%) have a favorable disposition towards ISIS. [23] However, this percentage gets to $27 \%$ with those of age 18-24 years old. In Germany it reaches to 3-4\% with no difference amongst age.

\section{Main Implications of ISIS}

ISIS has significant implications in the region and worldwide, these include the following:

1. Iraq: ISIS facilitated the disintegration of the country into several ethnic and re- ligious parts. Different displacement trends took place in Iraq including: Shabak and Turkmen Shia Minorities from Ninewa Governorate, Christian Minorities from the Ninewa Plains, Yazidi Minorities from Sinjar and surrounding areas, mixed dis- placement from Northern Diyala Governorate. [24] Furthermore, distinct ethnic re- gions are formed in the Kurdish region in the north, Shia region in the center and south, ISIS controlled region in the north and west of Iraq. Mainly, ISIS used three strategies in the Iraqi region, first the mass targeting of civilians and sites through brutal attacks on regions including Shia, Christian and other rivals; second, targeting military personnel and opponents; lastly, targeting internationals to send their antic- ipated message. 
2. Syria: ISIS has managed to control the northern and eastern parts of Syria. Again it facilitated the disintegration of the country through those with the regime and those against the regime. ISIS is fighting the Assad regime along with the other rebels in- cluding al-Nusra Front. Most recently, the US agreed with Turkey to train and equip the rebels, this will make the situation more volatile. Also, ISIS used the same three military strategies used in Iraq.

3. The Middle East: the concept of Jihad is widening in the area and ISIS is gaining support and allegiance from several Islamic and Jihadist groups, this increases the possibility of creating a welcoming region towards ISIS, especially with the messages in which ISIS presents itself as the savior of the true and ideal Islam. The military strat- egy used in the Middle East was through social media and aimed to attract personnel through the Jihad concept and philosophy and through potential sexual activity during the Jihad or promises of such affairs after death.

4. International World: ISIS recruits some of its personnel from all over the world includ- ing North Africa and Europe, and mostly from the Arab World. Through its strategy it is affecting the weapons and petrol prices in the region. The military strategy used is again through social media by sending terrifying videos on one hand and by sending attracting messages to recruit personnel on the other hand. In 2015 ISIS attacked 24 times [25] and killed more than 500 people outside Syria and Iraq. The recent death toll is very high: more than 120 in the Paris attack, 224 in a Russian plane above Egyt's Sinai Peninsula, more than 100 in Istanbul and almost 40 in Beirut. ISIS has made a significant turn to focus on external operations because it very likely wants to compensate for the lost territory in Iraq and Syria. The choreographed Paris attacks signal a dangerous departure from the group's typical low-tech to lone-wolf assaults representing high threats for European countries.

The recent developments shows that ISIS continues to execute its global strategy to de- fend its terrain within Iraq and Syria, to foster affiliates in the Middle East, North Africa, and Central Asia, and to encourage and resource terror attacks in the wider world. 


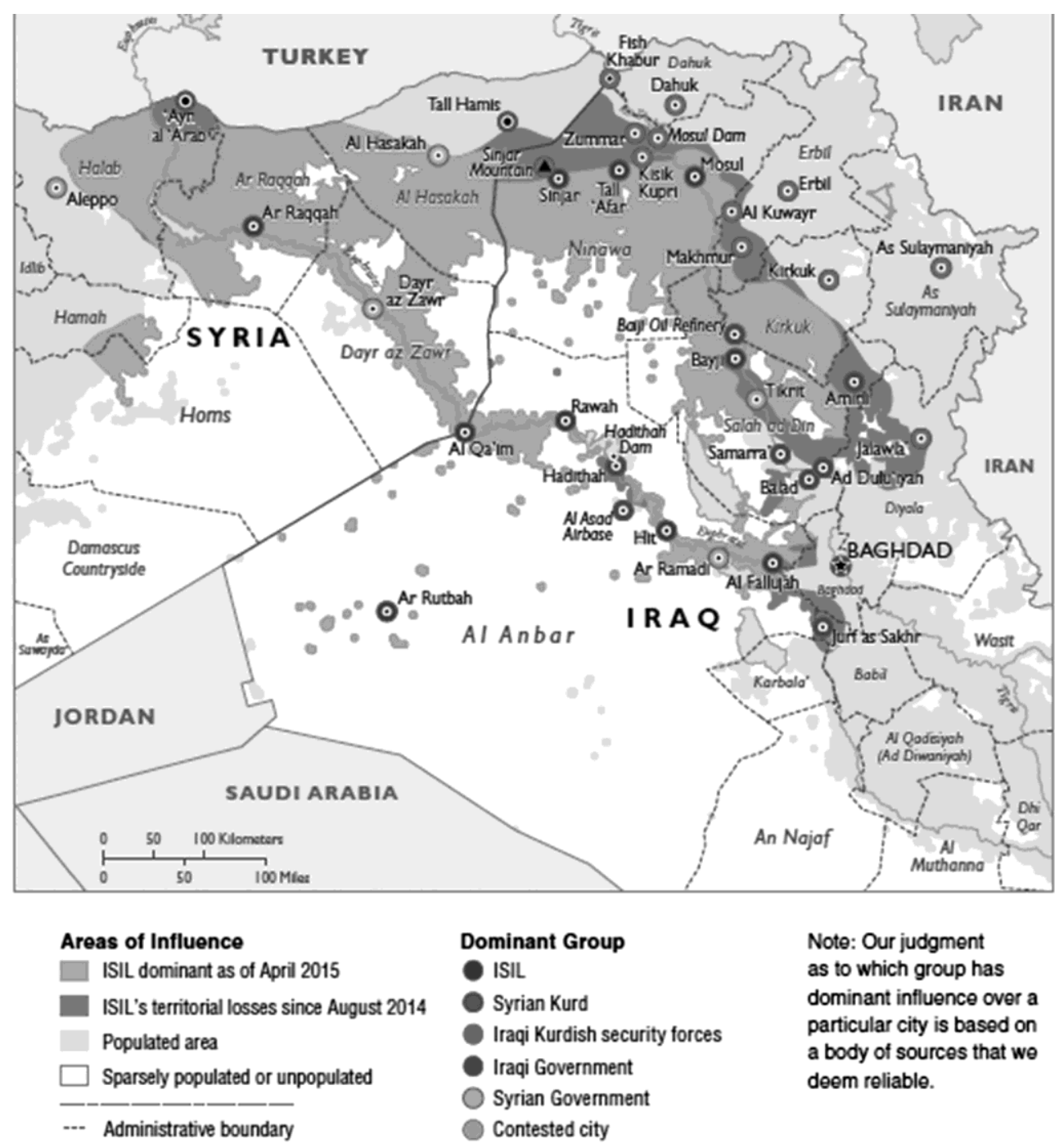

Figure 4. ISIS's Reduced Operating Areas (April 2015). [26]

\section{US-Led International Intervention against ISIS}

ISIS expansion has affected the US policy along with the international community policy in the region of Iraq and Syria. During its establishment, the US did not pay attention towards ISIS; their perspective was that rebels should play a role against the non-democratic Assad regime. However, after the wide expansion of ISIS this perspective changed. During the pe- riod June-August 2014, the US supported the local forces in the hope of terminating ISIS at- tacks. [27] In September, this strategy changed and a military air attack was enforced through a US-led coalition (Operation Inherent Resolve - OIR) without the use of ground troops. The coalition included Western and Arab countries. As of December 1, 2015, the countries that have participated in air strikes include: in Iraq: (1) Australia, (2) Belgium, (3) Canada, (4) 
France, (5) Jordan, (7) the Netherland, and (8) United Kingdom; in Syria: (1) Australia, (2) Bahrain, (3) Canada, (4) France, (5) Jordan, (6) Saudi Arabia, (7) Turkey, and (8) UAE. Ger- many will also be joining the air strikes very soon. As of $1^{\text {st }}$ December, 2015, the US and co- alition have conducted a total of 8,573 strikes (5,639 Iraq, 2,934 Syria). As of $28^{\text {th }}$ November,

2015, the US and partner nation aircrafts have flown an estimated 59,015 sorties in support of operation in Iraq and Syria. Operation Inherent Resolve attacks destroyed/damaged 16,075 targets (tanks, military vehicles, staging areas, fighting positions, buildings), and killed a half dozen ISIS leaders and leading individuals. As of $15^{\text {th }}$ November, 2015, only the US cost of operations alone since kinetic operations started on $8^{\text {th }}$ August, 2014, reached 5.2 billion US dollar with an average daily cost of 11 million US dollar. [28] Currently, the US is moving again to the strategy of equipping and training rebels. However, all these strategies are not helping halt ISIS's brutal activities; they are bringing more chaos and insecurity within the region and in Europe.

In addition to US-led international coalition, Russia has also joined the air strikes on $30^{\text {th }}$ September, 2015. The Russian military intervention was based on the request of the Syrian government to help against rebel and jihadist groups in Syria. Russia started air operations in north-western Syria against militant groups opposing the Bashar alAssad regime, including al-Nusra Front, ISIS, and the Army of Conquest. The Russian Space and Air Force enjoys significant ground support from the Syrian military, Iranian Revolutionary Guards, and allied militants. The situation as it developed in October 2015, was widely assessed to be a proxy war between the United States and Russia. By $17^{\text {th }}$ November, 2015, according to the Rus- sian Defense Ministry, Russia's air force had flown a total of 2,300 missions over Syria. [29] After the terrorist attack against the Russian Flight 9,268 Russia intensified the air campaign and supported by the land operations of Syrian governmental forces. As a result, for the first time in 4 years of war the Syrian Army liberated 80 inhabited areas, assuming control over a territory of 500 square kilometers. [30]

\section{Conclusion}

With all the brutal operations of ISIS, it remains an organized group with a mission to end the Sykes-Picot Agreement ${ }^{9}$ and establish a state that fills a wide range of geographic re-gions. Starting with Iraq and Syria as a point of departure to empower themselves and then start their next phases. Hence, it is based on religious rather than national unity. The area of control at the beginning was increasing over time, and their fierce fights are also increasing.

ISIS is playing it right, it has the financial resources, it is very well organized, it is using the media effectively, and it started providing health, educational services, and community outreach. It is getting to the grassroots. It is attracting and recruiting youth from all over the world. Those youth are amazed and proud that they will be part of this movement.

Despite the International coalition to fight against ISIS, this group is gaining so much support from different parties throughout the globe. They are receiving much support from

9 The Sykes-Picot Agreement, officially known as the Asia Minor Agreement, was a secret agreement between the governments of the United Kingdom and France with the assent of Russia defining their proposed spheres of influence and control in the Middle East should the Triple Entente succeed in defeating the Ottoman Empire during World War I. The negotiation of the treaty occurred between November 1915 and March 1916. The agreement was concluded on 16 May 1916. [31] 
the Middle East. The Taliban is an ally and the Islamic Moroccan group has announced their support according to their reports. Ansar Bayt Al-Maqdis in Egypt has sworn their allegiance. Additionally, it is worth to noting that this group has supported the Islamic brotherhood in Egypt; hence, the possibility that allies will not only be in the Sinai region. Moreover, Hamas in the Gaza Strip considers itself an Islamic party more than a national party. Especially since they supported the Islamic brotherhood when they took control of the government in Egypt. During that time relationships with Egypt enhanced. This relationship was not a result of national gathering but rather an Islamic gathering. Additionally, several announcements have been distributed in Gaza during the past few weeks with the ISIS name, along with several ISIS flags found in the region. If Hamas is not an ally in the current phase, it might be in the future due to the common values.

Support of ISIS can also be found in the European region. Despite all their extremist ac- tivities they have supporters within the Muslim youth in European countries. There is danger as the terrorist attack indicated in Paris that the "foreign fighters" could return to their home country to disrupt the state and public order. At the same time, a mass shooting in San Ber- nardino, California, shows that ISIS continues to pose a direct threat not only to Europe, but to U.S. as well, due to its robust network of regional affiliates and global supporters.

ISIS has been established in a fertile and convenient environment. It started in weak states; in Iraq, in the conflict between the Kurds, Sunni and Shia, and in Syria between the rebels and the Assad regime. This conflict allowed them to excel and boost, and as long as the conflict will remain this will be their harvest. This fertile environment gives a high opportu- nity to sustain if not expand. Kurds are fighting them, but the reason for their fights is to gain their own independence. Turkey is not in favor of the Kurds winning, thus they threaten the Kurdish rebels in their region. The conflict with ISIS acts as a catalyst. Any more conflicts in Gaza or Jordan will attract ISIS.

By the end of November 2015, it has become clear that there is a new ISIS global strategy. In the center of the concept stands the defense and expansion of an operational area control in Iraq and Syria. ISIS is building two rings around the "home territory": the closer abroad ring is designed to establish affiliates (currently eight countries exist) and increased disorder as we saw in November. In the far abroad ring ISIS will continue to launch terrorist attacks and to polarize the enemy.

However, it is thought, that the posing a threat to Europe and US, the attack in Paris, bombing the Russian Plane, and the massive attacks in the near and far abroad could change the western attitude towards ISIS. The European Union for the first time in its history - invoked the mutual defense clause 42.7 on $17^{\text {th }}$ November to assist France by all means in their power. The UN Security Council Resolution unanimously approved on $20^{\text {th }}$ November all necessary measures to fight the global and unprecedented threat of ISIS in the wake of the Paris attack. There is a chance to establish a "great coalition" between US, EU and Russia which could bring the change in the fight against ISIS. 


\section{References}

[1] PERI: Modern Conflicts: Conflict Profile. Iraq - Kuwait (1990-1991). Massachusetts: University of Massachusetts Amherst, Political Economy Research Institute, s.d. www.peri.umass.edu/fileadmin/pdf/Iraq3.pdf (downloaded: 1103 2015)

[2] WHITE, J. TABLER, A. J., ZELIN, A. Y.: Syria's Military Opposition. How Effective, United, or Extremist? Policy Focus, 128 (2013), 1-48. www.washingtoninstitute.org/ uploads/Documents/pubs/PolicyFocus128WhiteTablerZelin.pdf (downloaded: 1708 2015)

[3] GARTENSTEIN-ROSS, D.: How many fighters does the Islamic State really have? War on the Rocks (online), February 9, 2015. http://warontherocks.com/2015/02/how-many- fighters-does-the-islamic-state-really-have (downloaded: 1811 2015)

[4] GALGÓCZI I.: Az Iszlám Állam megszületése (Born of IS.) Seregszemle, XIII 1 (2015), 109-110.

[5] TAKÁCS I.: Az Iszlám Állam terrorszervezet kialakulása, müködése és jövőbeni lehetőségei. (Birth, operation and future prospects of ISIS terrorist organization.) Honvédségi Szemle, 1433 (2015), 35-36.

[6] LISTER, C.: Profiling the Islamic State. Analysis Paper, 311 (2014).

[7] The Global Intelligence files. http://wikileaks.org/gifiles/docs/36/3615824_translation- statement-of-mujahidin-shuracouncil-on.html (downloaded: 2302 2015)

[8] LAVENDER, L.: The Re-Awakening of Anbar. Mons: NATO Civil-Military Fusion Centre, 2013. www.irinnews.org/pdf/20130415_thematic_anbar_province_final.pdf (downloaded:

2202 2015)

[9] CORDESMAN A., KHAZAI, S.: Iraq after US withdrawal: US policy and the Iraqi search for security and stability. Washington, D.C.: Center for Strategic and International Studies,

2012. http://csis.org/files/publication/120702_Iraq_After_US_Withdrawal.pdf (downloaded: 2202 2015)

[10] HAMZA, M.: The al-Nusra: From Formation to Dissension. Doha: Arab Center for Research and Policy Studies, 2014. http://english.dohainstitute.org/file/get/9dd86818-731440ec-bf8e-be4a0db226c0.pdf (downloaded: 2402 2015)

[11] KIS-BENEDEK J.: The Islamic State and the Intelligence. Nemzetbiztonsági Szemle, (National Security Review), Special Issue (2015), 35-48. http://uni-nke.hu/uploads/media_items/nemzetbiztonsagi-szemle-2015_-angolkulonszam.original.pdf (downloaded: 1011 2015); http://pamelageller.com/2014/06/islamic-state-map-world-militants-outline-chilling- five-year-plan-globaldomination-declare-formation-caliphate.html/ (downloaded: 2001 2015)

[12] MOHAMEDOU, M.: ISIS and the Deceptive Rebooting of al-Qaeda. Geneva: Geneva Center for Security Policy, 2014. http://reliefweb.int/sites/reliefweb.int/files/resources/ ISIS\%20and \%20the\%20Deceptive\%20Rebooting\%20of\%20A1\%20Qaeda.pdf (downloaded: 1803 2015)

[13] SCOTT, M.: The ISIS Story. New York: Foreign Policy Association, 2014. http://foreignpolicyblogs.com/2014/07/03/the-isis-story/ (downloaded: 1503 2015)

[14] NERIAH, J.: The Structure of the Islamic State ISIS. Jerusalem: Jerusalem Center for Public Affairs, 2014. http://jcpa.org/structure-of-the-islamic-state/ (downloaded: 1503 2015) 
[15] BENDER, J.: As ISIS Routs the Iraqi Army, Here's a look at what Jihadist have in their arsenal. Business Insider (online), July 8, 2014. www.businessinsider.com/isis-military- equipment-breakdown-2014-7?op=1 (downloaded: 1503 2015)

[16] Middle Easterners See Religious and Ethnic Hatred as Top Global Threat. Europeans and Americans Focus on Inequality as Greatest Danger. Washington, D.C.: Pew Research Center, 2014. www.pewglobal.org/2014/10/16/middle-easternerssee-religious-and-ethnic- hatred-as-top-global-threat/ (downloaded: 2003 2015)

[17] Arab Public Opinion and the Fight against ISIS. Washington, D.C.: Washington Institute, 2014. www.washingtoninstitute.org/uploads/Documents/infographics/Arab_Public_ Opinion_and_the_Fight_Against_ISIS_-_English.pdf (downloaded: 2103 2015)

[18] ALRASHED, A. R.: How much Support does ISIS enjoy? Al Arabya News, 23 June, 2014. http://english.alarabiya.net/en/views/news/middle-east/2014/06/23/How-much-support- does-ISIS-enjoy-.html (downloaded: 2804 2015)

[19] Pakistan Taliban vow support for ISIS fighters. Al-Arabya News, 5 October, 2014. http:// english.alarabiya.net/en/News/middle-east/2014/10/05/Pakistan-Taliban-pledges-support-to- ISIS-.html (downloaded: 2804 2015)

[20] BUSHRA, S.: Egypt's Ansar Bayt al Maqdis swears allegiance to ISI: statement. Al Arabya News, 4 November, 2014. http://english.alarabiya.net/en/News/middle-east/2014/11/04/ Egypt-s-Ansar-Bayt-al-Maqdis-swears-allegiance-toISIS.html (downloaded: 1203 2015)

[21] Islamic State website. http://the-islamic-state.blogspot.hu/2014/03/blog-post_22.html (downloaded: 2001 2015)

[22] GREENFIELD, D.: 80\% of London Muslims Support ISIS. Most young Muslims in the UK support ISIS. FrontPage Mag (online), 2014. www.frontpagemag.com/2014/dgreenfield/80- of-london-muslims-support-isis/ (downloaded: 2003 2015)

[23] GRANT, M.: 16\% of French Citizens Support ISIS, Poll Finds. Newsweek, 26 August, 2014. www.newsweek.com/16french-citizens-support-isis-poll-finds-266795 (downloaded: 2003 2015)

[24] Iraq IDP Crisis Overview. 3-18 August, 2014. http://reliefweb.int/sites/reliefweb.int/files/ resources/REACH_IRQ_InternalDisplacement_Report_August2014.pdf (downloaded: 25 02 2015)

[25] The world's fight against ISIS: 10 things to know. Miami Herald, 19 November, 2015. www.miamiherald.com/latestnews/article45474945.html (downloaded: 2011 2015)

[26] Strikes in Iraq and Syria. Washington, D.C.: US Department of Defense, s.d. www.defense. gov/News/SpecialReports/0814_Inherent-Resolve (downloaded: 0612 2015)

[27] ISIS: Portrait of a Jihadi Terrorist Organization. Ramat Hasharon: The Meir Amit Intelligence and Terrorism information Center, 2014. www.terrorism-info.org.il/Data/ articles/Art_20733/E_101_14_163836165.pdf (downloaded: 2502 2015)

[28] Strikes in Iraq and Syria. Washington, D.C.: US Department of Defense, www.defense.gov/ News/SpecialReports/0814_Inherent-Resolve (downloaded: 0612 2015)

[29] Авиация РФ с начала операции в Сирии совершила свыше 2 тысяч вылетов. РИА НОВОСТИ (online), 17. 11. 2015. http://ria.ru/syria_mission/20151117/1322962104.html (downloaded: 2111 2015)

[30] Минобороны России. www.facebook.com/permalink.php?story_fbid=1678935105682572\& id=1492252324350852 (downloaded: 2111 2015) 
[31] The Editors of the Encyclopedia Britannica: Sykes-Picot Agreement. Encyclopedia Britannica (online), London: Encyclopedia Britannica (UK) Ltd., s.d. www.britannica.com/ event/Sykes-Picot-Agreement (downloaded: 04012015 )

[32] www.ft.com/m/html/expandable-picture.htm. (downloaded: 1510 2015)

[33] No-fly zones: The legal position. BBC News, 19 February, 2001. http://news.bbc.co.uk/2/hi/ middle_east/1175950.stm (downloaded: 1510 2015) 